\title{
Pollen Storage and Pollination Studies for Maximization of Hybrid Seed Production in Sunflower (Helianthus annuus L.)
}

\author{
K. Parimala* and I. Swarnalatha Devi
}

Seed Research \& Technology Centre, PJTSAU, Rajendranagar, Hyderabad, India

*Corresponding author

\begin{abstract}
A B S T R A C T
The experiment was conducted to assess efficiency of pollen storage methods in sunflower by using the parental lines of sunflower hybrid APSH-66. The trial was laid out in a randomized block design with three replications and eight treatments. Analysis of variance revealed that treatment effects were significant for characters such as number of filled

\section{Keywords}

Sunflower, Pollen storage, Seed set (\%), Seed yield

\section{Article Info}

Accepted:

15 July 2018

Available Online:

10 August 2018 seeds per head, seed set (\%), seed husk ratio and seed yield per plant. Among the treatments studied, the seed set was more when pollination was done with fresh pollen followed by pollen stored under $-20^{\circ} \mathrm{C}$ and pollen stored in refrigerator for different storage periods. Though percent seed set and number of filled seeds per head were significantly higher when fresh pollen is used for pollination, it was statistically on par with pollen stored at $-20^{\circ} \mathrm{C}$ for 3 days. Pollen stored in room temperature showed less viability compared to other treatments and this resulted in reduction of number of filled seeds per head and seed set $(\%)$. Effect of pollen storage methods on seed quality parameters showed significant differences between the treatments for all the traits studied except germination percentage. Seedling vigour index was found to be significantly superior when fresh pollen was used for pollination but it was on par with the treatments, pollen stored in refrigerator for 3 days and pollen stored at $-20^{\circ} \mathrm{C}$ for 3 days. Based on the study it is suggested that in case of scarcity of pollen during pollination in hybrid seed production, pollen grains may be stored in $-20^{\circ} \mathrm{C}$ or in refrigerator and could be utilized effectively.
\end{abstract}

\section{Introduction}

Sunflower is one of the important oilseed crops in India and it is also a crop of choice for farmers due to its wider adaptability, high yield potential, shorter duration and profitability. Temperature and RH plays an important role in maintenance of pollen viability. In most systems, low temperature and low humidity prolong pollen viability.
Reasons for not achieving seed yield in the crop are: as the female parent is a homozygous inbred with poor nicking ability, deviation in male sterile and restorer lines during flowering due to seasonal variations, lack of synchronization between male and female lines and lack of availability of sufficient pollen during aberrant weather conditions. Andrei (1998) found that a different amount of pollen with varying 
degree of viability was released by the restorer lines in different seasons. In sunflower, pollen viability under ambient storage decreased drastically from 32 hours (79.4\% seed set) to 56 hours $(31.30 \%$ seed set), while pollen stored under controlled condition showed better viability from 32 hours ( $85.31 \%$ seed set) to 56 hours $(64.38 \%$ seed set) as reflected from their respective seed set percent (Kempegowda et al., 1992). Yadav (1994) studied the pollen viability of ' $\mathrm{R}$ ' lines of sunflower hybrids (KBSH-1, APSH-11 and LDMRSH-1) and found that duration of viability of stored pollen was longer in autumn plantings (28 to 36 hours) as compared to spring plantings ( 24 hours) in all three R-lines. Andrei and Tirdea (1999) observed up to 80 percent of pollen viability at room temperature for one week. Sumathi et al., (2007) reported that pollen grains may be stored either in refrigerator or in earthen pots filled with water and covered with wet cloth and utilized properly for hybrid seed production to get increased yield. Hence there is a need to have knowledge on pollen viability, its storage methods and its further application in hybrid seed production to obtain higher seed yield. In view of the above a study was undertaken to assess the efficiency of pollen storage methods and use of pollen for hybrid seed production in adverse conditions.

\section{Materials and Methods}

The experiment was carried out by using the parental lines (A x R) of sunflower hybrid APSH-66 viz., PCMS 1A x PR-3 during rabi 2014-15 at Seed Research and Technology Centre, Rajendranagar, Hyderabad. The trial was laid out in randomized block design with three replications and eight treatments combinations viz., $\mathrm{T}_{1}$ - Freshly collected pollen, $\mathrm{T}_{2}$ - Pollen stored in room at ambient condition for 1 day, $\mathrm{T}_{3}$ - Pollen stored in refrigerator for 3 days, $\mathrm{T}_{4}$ - Pollen stored in refrigerator for 5 days, $\mathrm{T}_{5}$ - Pollen stored in refrigerator for 7 days, $\mathrm{T}_{6}$ - Pollen stored in $20^{\circ} \mathrm{C}$ for 3 days, $\mathrm{T}_{7}$ - Pollen stored in $-20^{\circ} \mathrm{C}$ for 5 days and $\mathrm{T}_{8^{-}}$Pollen stored in $-20^{\circ} \mathrm{C}$ for 7 days. The parental lines were sown in 3:1 female to male planting ratio in block method. Parental seeds were hand dibbled with a spacing of $60 \mathrm{~cm}$ between rows and $30 \mathrm{~cm}$ between plants. Heads of seed parent and pollen parental lines were covered with cloth bags before anthesis to avoid cross pollination by insects in hybrid seed production. Pollen was collected from freshly opened male parents by using the camel hair brush and stored in air tight containers. Treatments were imposed by hand pollination using soft muslin cloth to avoid damage to stigma. Pollination was started from the day of opening of ray floret to till the completion of floret opening. After pollination the heads were covered with brown paper covers to avoid contamination by foreign pollen. Observations were recorded for head diameter $(\mathrm{cm})$, number of seeds per head, seed set (\%), seed husk ratio, seed yield per plant (g), germination (\%), seedling length $(\mathrm{cm})$ and seed vigour index. The data was collected from five randomly selected seed parent. The experimental data were statistically analysed by using the OPSTAT software.

\section{Results and Discussion}

Results revealed that treatment effects were significant for the traits studied except for head diameter (Table 1). Among the treatments, pollination with fresh pollen exhibited superiority over other treatments for most of the characters studied while pollen stored in room temperature for one day showed poor performance. Pollination with freshly collected pollen was found to be on par with the treatment pollen stored in $-20^{0} \mathrm{C}$ for 3 days with respect to number of filled seeds per head and seed set (\%) but it showed significant differences over other treatments 
for those traits. Pollen stored in $-20^{0} \mathrm{C}$ for 3 days was found to be statistically superior to pollen stored in refrigerator for 7 days, pollen stored in $-20^{\circ} \mathrm{C}$ for 7 days and pollen stored in room temperature for one day with respect to number of filled seeds per head (429.72), seed set percentage (82.86) and seed yield per plant $(22.57 \mathrm{~g})$. Significantly higher seed set (\%) and higher number of filled seeds/head was noticed in the freshly collected pollen and pollen stored in $-20^{\circ} \mathrm{C}$ for 3 days over pollen stored in refrigerator and $-20^{\circ} \mathrm{C}$ for 5 and 7 days each.

Table.1 Effect of pollen storage methods on seed yield and its components of sunflower

\begin{tabular}{|c|c|c|c|c|c|}
\hline Treatment & $\begin{array}{c}\text { Head diameter } \\
(\mathbf{c m})\end{array}$ & $\begin{array}{c}\text { No. of filled } \\
\text { seeds } / \text { head }\end{array}$ & $\begin{array}{c}\text { Seed set } \\
(\%)\end{array}$ & $\begin{array}{c}\text { Seed husk } \\
\text { ratio }\end{array}$ & $\begin{array}{c}\text { Seed yield } \\
/ \text { plant }(\mathrm{g})\end{array}$ \\
\hline $\mathbf{T}_{\mathbf{1}}$ & 13.80 & $466.44^{\mathrm{a}}$ & $87.61^{\mathrm{a}}$ & $1.21^{\mathrm{a}}$ & $24.63^{\mathrm{a}}$ \\
\hline $\mathbf{T}_{\mathbf{2}}$ & 12.51 & $285.34^{\mathrm{e}}$ & $62.60^{\mathrm{e}}$ & $0.66^{\mathrm{c}}$ & $15.03^{\mathrm{d}}$ \\
\hline $\mathbf{T}_{\mathbf{3}}$ & 14.51 & $392.29^{\mathrm{bc}}$ & $74.69^{\mathrm{bc}}$ & $1.03^{\mathrm{ab}}$ & $20.86^{\mathrm{bc}}$ \\
\hline $\mathbf{T}_{\mathbf{4}}$ & 12.37 & $362.92^{\mathrm{cd}}$ & $70.24^{\mathrm{cd}}$ & $1.15^{\mathrm{a}}$ & $19.59^{\mathrm{bc}}$ \\
\hline $\mathbf{T}_{\mathbf{5}}$ & 12.71 & $326.16^{\mathrm{d}}$ & $66.93^{\mathrm{de}}$ & $1.02^{\mathrm{ab}}$ & $18.38^{\mathrm{cd}}$ \\
\hline $\mathbf{T}_{\mathbf{6}}$ & 12.71 & $429.72^{\mathrm{ab}}$ & $82.86^{\mathrm{a}}$ & $1.15^{\mathrm{a}}$ & $22.57^{\mathrm{ab}}$ \\
\hline $\mathbf{T}_{\mathbf{7}}$ & 13.42 & $363.79^{\mathrm{cd}}$ & $77.13^{\mathrm{b}}$ & $0.91^{\mathrm{b}}$ & $21.51^{\mathrm{abc}}$ \\
\hline $\mathbf{T}_{\mathbf{8}}$ & 12.79 & $342.13^{\mathrm{cd}}$ & $71.66^{\mathrm{cd}}$ & $1.06^{\mathrm{ab}}$ & $18.98^{\mathrm{c}}$ \\
\hline $\mathbf{C D}^{\mathbf{C}}$ & N.S. & 53.03 & 5.09 & 0.21 & 3.50 \\
\hline $\mathbf{S E} \mathbf{d}$ & 1.08 & 24.49 & 2.35 & 0.09 & 1.62 \\
\hline $\mathbf{C V}$ & 10.06 & 8.05 & 3.84 & 11.72 & 9.80 \\
\hline
\end{tabular}

$\mathrm{T}_{1}$ - Freshly collected pollen, $\mathrm{T}_{2}$ - Pollen stored in room at ambient condition for 1 day

$\mathrm{T}_{3}$ - Pollen stored in refrigerator for 3 days, $\mathrm{T}_{4}$ - Pollen stored in refrigerator for 5 days

$\mathrm{T}_{5}$ - Pollen stored in refrigerator for 7 days, $\mathrm{T}_{6}$ - Pollen stored in $-20^{\circ} \mathrm{C}$ for 3 days

$\mathrm{T}_{7^{-}}$- Pollen stored in $-20^{\circ} \mathrm{C}$ for 5 days, $\mathrm{T}_{8^{-}}$Pollen stored in $-20^{\circ} \mathrm{C}$ for 7 days

Table.2 Effect of pollen storage methods on seed quality parameters of sunflower

\begin{tabular}{|c|c|c|c|c|c|}
\hline Treatment & $\begin{array}{c}\text { Germination } \\
\%\end{array}$ & $\begin{array}{c}\text { Seedling } \\
\text { length }(\mathrm{cm})\end{array}$ & $\begin{array}{c}\text { Seedling fresh } \\
\text { weight }(\mathrm{cm})\end{array}$ & $\begin{array}{c}\text { Seedling dry } \\
\text { weight }(\mathrm{cm})\end{array}$ & SVI-I \\
\hline $\mathbf{T}_{\mathbf{1}}$ & 96.33 & $21.1^{\mathrm{a}}$ & $4.68^{\mathrm{ab}}$ & $0.15^{\mathrm{a}}$ & $2039^{\mathrm{a}}$ \\
\hline $\mathbf{T}_{\mathbf{2}}$ & 90.67 & $16.29^{\mathrm{d}}$ & $3.68^{\mathrm{c}}$ & $0.11^{\mathrm{bc}}$ & $1476^{\mathrm{d}}$ \\
\hline $\mathbf{T}_{\mathbf{3}}$ & 93.00 & $19.87^{\mathrm{ab}}$ & $3.82^{\mathrm{c}}$ & $0.12^{\mathrm{abc}}$ & $1850^{\mathrm{ab}}$ \\
\hline $\mathbf{T}_{\mathbf{4}}$ & 94.00 & $18.74^{\mathrm{bc}}$ & $4.71^{\mathrm{ab}}$ & $0.14^{\mathrm{ab}}$ & $1762^{\mathrm{bc}}$ \\
\hline $\mathbf{T}_{\mathbf{5}}$ & 91.03 & $17.66^{\mathrm{cd}}$ & $3.71^{\mathrm{c}}$ & $0.10^{\mathrm{c}}$ & $1610^{\mathrm{cd}}$ \\
\hline $\mathbf{T}_{\mathbf{6}}$ & 95.00 & $19.62^{\mathrm{abc}}$ & $4.99^{\mathrm{a}}$ & $0.13^{\mathrm{abc}}$ & $1866^{\mathrm{ab}}$ \\
\hline $\mathbf{T}_{\mathbf{7}}$ & 93.33 & $18.07^{\mathrm{bcd}}$ & $4.36^{\mathrm{abc}}$ & $0.14^{\mathrm{ab}}$ & $1687^{\mathrm{bcd}}$ \\
\hline $\mathbf{T}_{\mathbf{8}}$ & 94.33 & $17.91^{\mathrm{bcd}}$ & $4.07^{\mathrm{bc}}$ & $0.12^{\mathrm{abc}}$ & $1685^{\mathrm{bcd}}$ \\
\hline $\mathbf{C D}$ & N.S. & 2.09 & 0.75 & 0.03 & 212 \\
\hline
\end{tabular}

$\mathrm{T}_{1}$ - Freshly collected pollen, $\mathrm{T}_{2}$ - Pollen stored in room at ambient condition for 1 day

$\mathrm{T}_{3}$ - Pollen stored in refrigerator for 3 days, $\mathrm{T}_{4}$ - Pollen stored in refrigerator for 5 days

$\mathrm{T}_{5}$ - Pollen stored in refrigerator for 7 days, $\mathrm{T}_{6}$ - Pollen stored in $-20^{\circ} \mathrm{C}$ for 3 days

$\mathrm{T}_{7}$ - Pollen stored in $-20^{\circ} \mathrm{C}$ for 5 days, $\mathrm{T}_{8^{-}}$Pollen stored in $-20^{\circ} \mathrm{C}$ for 7 days 
The treatments pollen stored in refrigerator for different durations (3 days, 5 days and 7 days) exhibited significantly increased the number of filled seeds per head, seed husk ratio and seed yield per plant compared with the treatment pollen stored in room temperature for one day. Though the seed husk ratio was higher in the treatments freshly collected pollen, pollen stored in refrigerator for 5 days and pollen stored in $-20^{\circ} \mathrm{C}$ for 3 days it was on par with treatments pollen stored in refrigerator and $-20^{\circ}$ $\mathrm{C}$ for 5 and 7 days each. The least number of seeds per head (285.34), seed set percentage (62.60), seed husk ratio (0.66) and seed yield per plant $(15.03 \mathrm{~g})$ was recorded in pollen stored in room temperature for one day. Due to availability of more viable pollen for pollination in the treatments freshly collected pollen and pollen stored in $-20^{\circ} \mathrm{C}$ for 3 days resulted in increased number of filled seeds per head, seed set $(\%)$, seed husk ratio and seed yield per plant.

Effect of pollen storage methods on seed quality attributes of sunflower exhibited significant differences among the treatments. Variability due to treatments was significant for the parameters studied except for germination percentage (Table 2). The treatment, pollination with freshly collected pollen showed higher germination $(96.33 \%)$, seedling length $(21.16$ $\mathrm{cm})$ and seed vigour index (2039). Least germination percentage (90.67) and seed vigour index (1476) were observed in pollen stored in room temperature for one day. Freshly collected pollen showed significantly higher seedling vigour over other treatments but is was on par with pollen stored in refrigerator for 3 days and pollen stored in $-20^{0} \mathrm{C}$ for 3 days. Similar trend was noticed for seed vigour index. The pollen stored in $-20^{\circ} \mathrm{C}$ for 3 days showed significant superiority for seedling length (19.62) and seedling vigour index (1866) compared with the treatment pollen stored in room temperature for one day. The vigour index was influenced by good germination and seedling length which in turn were due to better seed filling. Based on the results it is suggested that in case of scarcity of pollen during pollination in hybrid seed production, pollen grains may be stored in $20^{\circ} \mathrm{C}$ or in refrigerator and could be utilized effectively to maximize the hybrid seed yield and better economic returns.

\section{References}

Andrei, E. 1998. Determination of the pollen amount in pollen fertility restorer sunflower inbred lines. Cercetari Agronomice in maldova, Romania. 31: 111-120.

Andrei, E and Tirdea, G. 1999. Viability of sunflower pollen. Cercetari Agronomice in Maldova, Romania. 31: (3/4) 121126.

Kempegowda, H. 1992. Effect of planting design and staggered sowing of parental lines on seed yield and quality in KBSH-1 Hybrid sunflower (Helianthus annuus L.). M.Sc., (Agri.) Thesis, Uni. Agril. Sci., Dharwad (India).

Sumathi P., Nirmala Kumari, A and Jhonjoel. 2007. Effect of storage techniques on pollen viability in hybrid seed production of sun flower (Helianthus annuus. L.) soil Journal of Research, SKUAST-J. 6(1):41-46.

Yadava, O.K., Sangwan, R.S. and Yadav, O.P. (1994). Evaluation of pollination methods for hybrid seed production in sunflower (Helianthus annuus L.). Crop Research, 8(3): 512.516.

\section{How to cite this article:}

Parimala, K. and Swarnalatha Devi, I. 2018. Pollen Storage and Pollination Studies for Maximization of Hybrid Seed Production in Sunflower (Helianthus annuus L.). Int.J.Curr.Microbiol.App.Sci. 7(08): 2661-2664. doi: https://doi.org/10.20546/ijcmas.2018.708.275 